\title{
English for specific academic purposes: The need for ICT and reconstruction
}

\section{Yahya Dkhissi \\ English Department, Chouaib Doukkali University, El Jadida, Morocco}

\section{Email address:}

Yahya.dkhissi@gmail.com

\section{To cite this article:}

Yahya Dkhissi. English for Specific Academic Purposes: The Need for ICT and Reconstruction. International Journal of Literature and Arts. Special Issue: Discourses of Militarization and Identity: Literature of Conflict. Vol. 2, No. 6-1, 2014, pp. 1-7.

doi: 10.11648/j.ijla.s.2014020601.11

\begin{abstract}
In most non-English speaking countries, the language is basically seen as an academic endeavor for some general or specific purposes. Teachers, academicians, syllabus designers, but not learners, are often involved in structuring, designing or promoting the curricula and teaching activities. The rationale of this paper is to integrate other contributing components to the teaching and learning of English for Specific Academic Purposes (ESAP). Authentic material, ICT, learners' communication, task based activities, the teacher's facilitator role, digital teaching, purpose oriented assessment, learner centered methods and project oriented curricula are the current needs of higher education in the Moroccan university. Thus, the objective of this paper is to give some new insights that might contribute in the digital change and the current needs of learning and teaching enterprise. For this purpose, a case study of teaching some linguistic and research methods courses has been conducted in the English department at Chouaib Doukkali University, El Jadida, Morocco, to evaluate to current situation, analyze the data and suggest a reconstructive model based on ICT and learners' integration.
\end{abstract}

Keywords: ESAP, ICT. Linguistics, Digital Teaching, Reconstructive Model

\section{Introduction}

Most of the research in the field of English teaching has highlighted the need to embrace a given identity for English for Academic Purposes (EAP) (Flowerdew \& Peacock, (2001); (Hyland \& Hamp-Lyons, 2002), and Strevens (1988)). EAP is also differentiated from other purposes which are specific or general in that it focuses on helping learners to study, conduct research, enhance communicative needs and understand the specific academic disciplines. Although the teaching methodology and the skills to be fostered are not specified in EAP teaching, it is claimed by Watson Todd (2003) that EAP promotes the development of learner autonomy and exploits new technology. Other researchers have stressed the need for EAP"s institutional awareness and the use of materials informed by corpus-enhanced genre studies and critical pedagogy (Krzanowski, 2001; Sharpling, 2002; Bell, 2005; Alexander, 2012). These requirements would probably unveil the striking issue of teaching methods and curricula designed for specific purposes of EAP (henceforth ESAP). According to Flowerdew \& Peacock (2001, p177) 'a critical step in designing the EAP curriculum is accepting that the methodologies and approaches valid in any other area of ESL are not necessarily the most appropriate for EAP.' Teachers are sensitized first to account for what is done, how it is done and for what academic and specific professional purposes; second, they have to foster learners' skills with regard to their needs, objectives and outcomes.

Accordingly, the main objective of the current paper is to account for the idea that teaching of some linguistic courses, research methods at the Moroccan university requires some special understanding of learners' needs and objectives, a selection of the appropriate tasks and teaching methods, and a practical assessment while monitoring learner's progress to provide effective intervention. It will be demonstrated in this paper that the use of English for specific academic purposes (ESAP) is not only a content based activity where only the delivery of knowledge should be carried out. It is however an experience inside an academic environment that requires careful practical aspects of planning and teaching. Students may not be able acquire everything they need to learn nor can they learn effectively from a random collection of content, exercises and assignments. 
Teachers and syllabus designers should make a number of key decisions to meet the high-stakes EAP learner needs, teaching approaches, tasks, materials and assessment methods that will enable a better academic performance.

ESAP is taught for a variety of academic purposes all over the world, each with its own local constraints, available materials and resources, teacher preferences and learner goals. Thus, linguistic, social, professional development and needs awareness might be the starting point from where we can determine the overall teaching model. These needs will accordingly distinguish an ESAP course from general language teaching (Dudley-Evans and St John, 1998; Hutchison and Waters, 1987). Actually, Needs is a broad term that might embrace learners' goals and backgrounds, their language proficiencies, their learning-teaching preferences, and the contexts where they will need to take part in. According to Dudley-Evans and St John, (1998), it is quite accurate to distinguish between present situation analysis and target situation analysis.

The Present situation analysis concerns 'starting where the students are' and refers to information about learners' current proficiencies and ambitions: what they can do and what they want at the beginning of the course; their skills and perceptions; their familiarity with the specialist subject; and what they know of its demands and genres. However, Target situation analysis concerns the learners' future roles and the linguistic skills and knowledge they need to perform competently in their disciplines. This relates to communication needs rather than learning needs and involves mainly objective and product-oriented data: identifying the contexts of language use, observing the language events in these contexts, and collecting and analysing target genres. However, this might be a challenging move as EAP materials and curriculum do no lend themselves to a communicative approach to teaching but to lecture and information transfer.

\section{The Teaching-Learning Situation}

The Moroccan educational system has been introduced to a new reform that was drafted in 1999 and finalized in 2000. The reform has focused on practical issues besides the institutional and pedagogic ones. The need to make the teaching as linked to the current needs of the Moroccan market and job requirements. However, after a decade, the Moroccan higher educational system did not fulfill most of the requirements in the national charter. Thus, the current paper targets, through a study of linguistic courses in the English department, a better teaching for a better academic performance. The main belief is that teaching of some linguistic courses at the Moroccan university requires some special understanding of learners' needs and objectives, a selection of the appropriate tasks and teaching methods, and a practical assessment while monitoring learner's progress to provide effective intervention.

Students belonging to the English department use a wide range of strategies in language learning given their awareness of some valuable categories of learning strategies. The most relevant strategies are fairly self-management and selfevaluation strategies in that they are self-regulatory strategies in which the BA students that participated in the questionnaire have claimed to be aware of while evaluating their own learning endeavors. Most of the students have claimed the importance of the linguistic courses they are supposed to rate. These courses include phonetics and phonology, applied linguistics, language teaching, and research methods.

\section{ESAP in Higher Education}

Within the higher education community, a huge amount of teaching for specific academic purposes takes place. However, whether this specific academic teaching is effective or not is the most legal question. According to Centra (1993), effective teaching is simply "that which produces beneficial and purposeful student learning through the use of appropriate procedures" (1993: 42), other scholars like Braskamp and Ory, (1994: 40) assume that effective teaching is the "creation of situations in which appropriate learning occurs; shaping those situations is what successful teachers have learned to do effectively".

Moroccan university students are in effect able to discern practical content, quality, relevance, usefulness, and teacher interference and integration through what is taught and how it is taught. Students are certainly qualified to rate the learning-teaching enterprise and can report the extent to which the experience is beneficial, productive, and objectiveoriented. Sociocultural attitudes and practices also need to be considered to avoid forcing unwelcome methods or course content that would result in learners' surrender to the ideologies involved in the syllabus as well as the pedagogical and cultural frustrations with the curriculum and the text book. (See the Sri Lanka case study in Canagarajah (1999: 5), the South African case in Chick (1996), and the Egyptian case in Halliday (1994).

According to the current research, an evaluative stance to knowledge, teaching methods, and available sources should be examined and therefore enhanced. Many university students favor to conserve and reproduce existing knowledge through strategies such as memorization. In Bereiter and Scardamallia's (1987) terms this is 'knowledge telling' which represents immature writing, where the learner tries merely to say what he or she can remember based on the assignment. Effective learning at the beginner and intermediate level might be the natural outcome of effective teaching with respect to the learners' needs and the teacher's creativity in terms of contexts, procedures and materials. However, the current situation involves some intermediate and advanced learners of English as a foreign language. In this ESAP classroom, the teacher might be influenced by the fact that students use previous specialized knowledge and learning processes from other disciplines to this specific linguistic class. The teachermay build on these to develop learners' language and discourse understandings might use a variety of 
methods, some of which are summarized in Table 1:

Table 1. Teacher-learner collaboration (Feez, 1998: 27)

\begin{tabular}{ll}
\hline Scaffolding & Learner Progress \\
\hline $\begin{array}{l}\text { Independent learner performance } \\
\text { Reduced teacher involvement }\end{array}$ & Potential performance \\
$\begin{array}{l}\text { Increased learner independence } \\
\text { Considerable teacher contribution }\end{array}$ & Zone of Proximal Development \\
Learner's entry level & Existing competence \\
\hline
\end{tabular}

The relationship within teaching-learning process should highlight according to Feez (1998) a reduced involvement of teachers, a motivated independent learner and an autonomous learning. For this reason among others, this paper assumes that an insightful study of linguistic teaching experience in Moroccan Higher Education is quite legitimate in order to appreciate the demands of academic study, and is fairly a prerequisite when applying for teaching, tourism, translation or related jobs to the linguistic courses under study. The Russian psychologist Lev Vygotsky (1978) claims that students' discourse competence in EAP classes requires giving considerable recognition to the importance of collaboration, or peer interaction, and scaffolding, or teachersupported learning. Learners will be assisted through two notions of learning: First, Shared consciousness where learners working together rather than individually learn more effectively; second, borrowed consciousness or scaffolding where learners working with other knowledgeable learners develop greater understanding of classroom activities, and would therefore move from a current academic performance to a potential academic performance level.

\section{The Research}

\subsection{Methodology}

80 students from the English department, Chouaib Doukkali University, El Jadida, Morocco, were asked to complete the questionnaire to rate the teaching method used in different linguistic courses namely: applied linguistics, phonology, and language teaching, besides research methods course. $26 \%$ rated the lecture method as the best teaching method because it is not time consuming and more informative. This method is economical, it can be used for a large number of students, the material can be covered in a structured manner and the teacher has a great control of time and reference materials. 59\% prefer the communicative approach where group discussion is prevailing because it offers authentic communicative settings devoid from any rote learning, while only $15 \%$ rated the data-driven method as a practical one to understand phonetics, phonology and morpho-syntax. On the other side, the corresponding teachers rated the eclectic method as the most practical one given its appropriateness to different teaching situations that enhance the quality of the enterprise where the learners' strategies are taken into consideration. Another suggested method by students is related to Project Based Learning which is a teaching method in which students acquire knowledge and skills by working for an extended period of time to investigate and respond to a complex question, problem, or challenge. This method is a form of presentation where a group of students work together to brainstorm, raise interest and enhance critical thinking to come up with practical suggestions for the linguistic item under study. Consider the following feedback of learners' strategies in learning linguistic courses:



Figure 1. Learners'strategies

This figure shows that 33\% rely on memorization and the information delivered by their teachers; whereas $50 \%$ learn independently and look for self-assurance. However, this category of students claimed that consciousness rising might be novel to them given it fosters creativity and reflection on what they read so that they can construct their own examples of the linguistic genres. This state of affairs is assumed, according to these students, to be related to the materials used in class namely lecturing, handouts and explanations when needed at the expense of stimulus materials that involve a full range of media. Less authentic materials would probably distract learners from any involvement in the progress of the academic endeavour involved in the teaching of somewhat scientific linguistic subjects.

\subsection{Classroom Materials and ICT}

The classroom materials and their implementation for a better academic achievement are usually a striking issue at the Moroccan university. Teachers are supposed to abide by the academic texts and the delivery of the content as a form of lectures, presentations or as explanatory hand-outs. As digital natives, these BA students were asked to rate the materials used in class and the relationship they have with their performance and assessment. Students' digital awareness was explicit in their rating of the classroom materials as inefficient: reading texts on applied linguistics, sociolinguistics, language teaching or morphology were assumed by $62 \%$ of the students to have very limited impact on their performance. The students comments were that poor performance is related to length and specific terminology, the texts designed do not fit the real life and market needs, the teacher talking time is extremely high while students' involvement is very low. However 20/ of students think that reading texts, reviewing and reflecting on them would help academic performance and might reduce the teacher's talking time (TTT) and empower their reflective thinking.. 
The use of PowerPoint presentations, Video reach to explanations, offline and online blogs were rated highly in that $85 \%$ wish for an implementation of digital teaching; while only $33 \% /$ admitted that they do actually use this elearning; while only $5 \%$ asked to maintain the face-to-face lecturing and reading texts-based teaching.

So, the current challenge is to accommodate the digital natives or (Millenniums) by provisioning for ICT integrated teaching and learning mode other than the conventional lecturing methods. The available sources can be summarised as the following:

1. Open educational resources (OERs),

2. Massive open online courses (MOOCs),

3. Wikis, Online and Offline Blogs, Podcasts ,Slide Share

4. Learning Management Systems (e.g. Web CT or Moodle).

With respect to the suggested sources, a primary move has been taken to check the possibility of the Moodle implementation in research methods course (RMC). Moodle works in a way where students are supposed to go online and deal with the course before it is delivered in class as in the following phonetics course:

Example:

Chapter one: Place and Manner of Articulation

- $\quad$ Reading text

- Teacher's notes

- quiz

The prospective objective of the course is to keep students informed and involved in the delivery of the course. Consider the following results after checking the number of visits of some 41 students attending the research methods course:

$\begin{array}{ll}\text { Activity } & \text { Number of visits } \\ \text { Reading } & 129 \\ \text { Lecture Notes } & 118 \\ \text { Quiz 1 } & 162 \\ \text { Quiz 2 } & 66 \\ \text { Problem Sheet } & 45\end{array}$

The reading activity seems accordingly not to be a burden for students as it is the case for content based courses like applied linguistics, semantics, pragmatics and sociolinguistics. The reason might be attributed first to the small size of the selected texts. Second, students attending the course of phonetics do benefit from the help of this elearning platform where they can check their performance while going through the quiz 1 and/or quiz 2. Lecture notes are an explicit explanation of the texts and the course as a whole. The poor number is the visits for problem sheet which reflects the inner need to learn explicitly and practically as the number of visits for quiz 1 shows.

Contrariwise, some $76 \%$ of students taking the applied linguistics course (ALC) were asked to rate the course of applied linguistics in terms of three simple questions:

1. What do you like about the applied linguistics course?

2. What don't you like about the applied linguistics course?

3. Any suggestions for the design and delivery of the applied linguistics course?

Note that the ALC is a content-based course where the teacher is not just a facilitator but the manager who decides about everything in class: the syllabus, the teaching method to be used, and the type of assessment. Lecturing and few power point presentations are the only means used in class. $85 \%$ rated the ALC as an important course that facilitates the understanding the social and cultural factors involved in language acquisition or learning. However, $78 \%$ appreciate the act of reading the texts assigned but most of them acknowledged some difficulty with the length of the texts assigned for reading and the complexity of the multitude definitions of major notions involved in the chapters. $20 \%$ admitted that they don't read the totality of the chapters but just skim and scan because they are not assessed for their reading but for their written performance either as a formative or summative evaluation. $4 \%$ suggested using ICT in teaching this course, giving presentations and reducing the number of readings, while $60 \%$ appreciated their teacher's energy and enthusiasm.

Notice that RMC offers through the use of Moodle more space and time for students to reflect on the materials and content assigned. The number of visits for readings in RMC rate 3 times the number of readings for ALC. This result is foregrounding issue for our reconstructive model in this paper. To enhance this model, another investigation in language teaching course (LTC) was undertaken as a semistructured interview with two groups involving 38 and 41 students respectively. $72 \%$ rated the presentation-delivery a very challenging and motivating method; while they have shown some readiness, contrary to ALC, to read the texts chosen because they represent their future interests. In this course, students are supposed to learn about the diverse teaching methods, learning strategies, teaching language skills and different proficiency levels as the major units of the course. Classroom management and curriculum development are also involved in the course as interactive items where the teacher tries to foster students' preferences and contentions.

As the teacher in charge of this course, I tried to sensitize students to the objective of the course as a first move to empower their ability to teach English and also to create a pseudo-teaching context for EAP.

Delivering a presentation using ICT was a usual practice in this course. PowerPoint, videos, tape recorded speeches, charts, and diagrams were an integral part of the course. $88 \%$ used the PowerPoint presentation and the accompanying devices to manage the classroom as a teacher and not only as a student delivering a presentation.

The students taking this course have been asked to adopt a learning strategy referred to as ACT and REACT strategy. ACT is an endeavour whereby every student experiences 3 minutes teaching in class where he or she chooses a given grammatical or functional item in English and tries to adopt a teaching method to deliver it as a course. Others have to REACT to the student's choice, the method, consistency, speech tone, classroom management and language use. Some 
$60 \%$ have acknowledged that they have never witnessed the use of videos in class at the faculty; while 55\% appreciated the opportunity rarely given to experience the teaching act. These reactions have encouraged a very interactive course that involved the practice of language teaching as an act and react strategy rather than acquiring knowledge in a specific academic context.

The major contention of students in English Department is that content based courses represent a heavy reading texts load that requires smart pacing of activities and reading. Students deal with applied linguistics, semantics and sociolinguistic courses as content and lecture based courses where the teacher is not a facilitator as in phonetics/phonology, research methods or language teaching course. This state of affairs undoubtedly requires special care and a reconstructive teaching method that might reconsider the learning role as an integral part of teaching (see the model below)

With respect to the BA students' feedback, we assume that teachers and syllabi designers, more than linguists, should take the following suggestions into account:

1. Collecting information needed to develop efficient ICT strategies by leveraging the available technologies to create interactive and innovative class atmosphere and provide key solutions to higher education problems of inappropriate methods to digital natives learning needs.

2. The implementation of academic linguistic skills as well as linguistic e-books.

3. The use of unified textbooks where most linguistic courses textbook are compiled in.

4. The use of academic textbooks made for the classroom context rather than research text-books.

5. An integration of ICTs into the educational system not only in terms of technology but also curriculum and pedagogy, with a certain institutional and teacher readiness, and continuous follow-up and financing.

6. The implementation of Moodle as an open-source Learning Platform.

\subsection{Assessment}

Generally, students preparing for the BA degree in Moroccan universities are assessed in terms of written formative and summative exams. The students preparing to complete the BA degree were asked to rate the exams in linguistic subjects. $42 \%$ find the way they are examined in linguistic subjects a challenging one, 37\% find it theoretical, and $21 \%$ find it helpful. Students are examined in linguistics in a challenging way where exams' design is sometimes unpredictable and might take into account different data analyses, reading materials, and lecture or presentations details.

Linguistic assessment tasks require a piece of writing with its broader objective meant to test students on tutorial component and homework based on sources produced by teachers; and without homework students would feel the exam content unfamiliar and not practical. A less stressful and free context however would require the implementation of e-portfolios which reflect the practice of academic linguistic tasks that can be done individually or in-group. These linguistic e-portfolios may involve phonological data analysis in Phonology course, written lesson plans in LTC, or organizing bibliographies in RMC.

However, if we follow the belief that students do remember only $20 \%$ of what they hear and learn while they need the other $80 \%$ to fulfil all academic requirements, it will be straightforward to call for group work where integration of online and offline sources might offer more practice and reflection on the classroom materials. Given the technical nature of the linguistic subjects, learners should be primarily advised to withdraw if not ready to make some commitments before and during evaluation time. Additionally, they should be told about the amount and hours of reading, time communication, how to evaluate and handle the assignment without relying on textbooks as a unique input but a reflected-upon output.

A constructive alignment idea is that, concerning curriculum development, academicians should ask teachers to teach and examine students differently and not the same way for many years. This way, students will be examined in an efficient method that would involve an integration of the required skills and their development with respect to the academic objectives of the assessment. The illuminating idea about the course can be purposefully exploited in the assessment by asking open ended questions, solving problem questions, attitudes towards various linguistic or skill-based phenomena, or even asking course related questions that were implicitly explained by the teacher.

\section{The Reconstructive Model}

For an efficient teaching of ESAP in Moroccan higher education to take place, contingency plans and credible assessment should ensure that the teaching-learning development is the output of the exploitation of the available ICT sources, the students' motivation and the teacher's readiness for change. Thus, some new prospects should be taken into account among which: graded presentations, online/offline quizzes, e-portfolios, and learners' participation in lesson planning and delivery; besides the motivation to solve phonological, syntactic, language teaching problems in terms of group work and reflective thinking in handling problems.

The model we would like to propose in this paper might help in reconstructing the delivery of the linguistic courses and a better academic performance. The model will exploit the students' linguistic awareness, the online or offline blogs, and the teachers' experience in the lesson planning and delivery. This model can be summarized as follows:

Table 2. The Standard Model

\begin{tabular}{ll}
\hline Content delivery & In class \\
\hline Practice Assessment & Teacher Oriented \\
Follow-up Homework & Learner Oriented \\
\hline
\end{tabular}


Table 3. The Reconstructive Model

\begin{tabular}{ll}
\hline $\begin{array}{l}\text { Readings, (suggested blogs, Slides, and wikis) } \\
\text { Teacher's notes or uploaded videos Inductive } \\
\text { learning }\end{array}$ & Online \\
$\begin{array}{l}\text { Brainstorm: Raising course questions } \\
\text { Feedback and Content delivery } \\
\text { Checking and developing learners", } \\
\text { Linguistic awareness } \\
\begin{array}{l}\text { Simulation and contextualization } \\
\text { Practice in group }\end{array}\end{array}$ & $\begin{array}{l}\text { Teacher-Learner } \\
\text { oriented In class }\end{array}$ \\
$\begin{array}{l}\text { Assessment (online ungraded worksheets) } \\
\text { Follow up via Moodle Homework (online quiz) } \\
\text { Online or in class Assessment feedback }\end{array}$ & Learner oriented \\
Problems statement (online) & Teacher Oriented \\
\hline
\end{tabular}

This reconstructive model looks forward to integrate two non-negligible factors in the teaching of ESAP in Moroccan higher education: ICT and the learner involvement. So often, students are considered in English departments as foreign learners that target the learning of the language itself and the skills required. However, teachers in English departments have different objectives associated with the nature of the linguistic course they are assigned to teach. On the other hand, students are straightforward in their choice to learn English because it ensures a teaching or a communicatively oriented job; however, academic performance does not entail a professional achievement given the current psychomotor domain that reflects the learners' inefficient communicative competence.

A correct practice of the reconstructive model will enable the teacher to

1. Foster the learner's responsibility in the delivery of the lesson.

2. Deal with queries appropriately and offers appropriate help to those that have demonstrated some linguistic difficulties in the follow-up or problems statements sections.

3. Use time efficiently in order to maximize opportunities for student learning.

4. Pace Activities in class or online with respect the attention span needed for each.

5. Satisfy learners' academic needs and their future professional objectives.

6. Make assessments a learning activity that is done online before it is done in class.

\section{Conclusion}

The teaching of ESAP in Moroccan English departments has not reflected the basic academic objectives and the current learners' needs. Thus, the ultimate aim of this paper is to take into consideration the digital generation and its needs to use the new technology and their professional needs as means and ends of e-learning/e-teaching dichotomy. Learners' ratings have shown their awareness of the new challenges that require their involvement in every step of the linguistic learning-teaching enterprise. ICT and Moodle are shown to be essential practices in lesson delivery and assessment. Given the different nature of the linguistic courses in question, a general reconstructive model is proposed to integrate the learner and teacher oriented activities with respect to the psychomotor and attention span of learners. In this model, teachers are considered as in-class facilitators and online teacher-counsellors. Most steps of the model are learner oriented to give credit to the creative and critical thinking of the students with regard to their academic expectations and professional development. The linguistic curriculum development should also be implemented and even changed if required satisfying this millennium generation.

\section{References}

[1] Alexander, O., Argent, S. and Spencer, J. (2008) EAP Essentials. A teacher's guide to principles and practice. Reading: Garnet Publishing Ltd.

[2] Alexander, O. (2012). Exploring teacher beliefs in teaching EAP at low proficiency levels. Journal of English for Academic Purposes 11, pp99-111

[3] BALEAP. (2008). Competency Framework for Teachers of English for Academic Purposes. Retrieved 26.05.12 from http://www.baleap.org.uk/teap/teap-competency-

framework.pdf

[4] Bell, D.E. (2005). Storming the Ivory Tower. ELT Gazette, June Issue. $p 7$.

[5] Bell, D.E. (2007). Moving Teachers from the General to the Academic: Challenges and Issues in Teacher Training for EAP. In T. Lynch \& J. Northcott (Eds). Symposia for Language Teacher Educators: Educating Legal English Specialists \& Teacher Education in Teaching English for Academic Purposes. Proceedings of IALS Teacher Education Symposia, 2004 and 2006. Edinburgh: Edinburgh University.

[6] Braskamp, L. A. (2000). Toward a more holistic approach to assessing faculty as teachers. In K. E. Ryan (Ed.), Evaluating teaching in higher education: A vision for the future. New directions for teaching and learning, 83, 109-123. San Francisco, Ca: Jossey-Bass.

[7] Braskamp, L. A., \& Ory, J. C. (1994). Assessing faculty work: Enhancing individual and instructional performance. San Francisco, CA: Jossey-Bass.Centra, J. A. (1993). Reflective faculty evaluation. San Francisco, CA: Jossey-Bass.

[8] Chang, T.S. (2001). The effect of system administration on faculty attitudes toward student ratings. Hualien, Taiwan: National Hualien Teachers College.

[9] Chick, K. (1996). 'Safe-talk: collusion in apartheid education.' In H. Coleman (ed.), Society and the language classroom. Cambridge: Cambridge University Press.

[10] Cohen, P. A. (1981). Student Ratings of Instruction and Student Achievement: A Meta-Analysis of Multisection Validity Studies. Review of Educational Research. 51, 281309.

[11] Cuseo, J. (n.d.). The case for student evaluation of college courses. Policy Center on the First Year of College. Retrieved May 27, 2002, from http://www.brevard.edu/fyc/fya/CuseoLink.htm 
[12] Dudley-Evans, T. and St. John, M.J. (1998) Developments in English for Specific Purposes. A multi-disciplinary approach. Cambridge: Cambridge University Press.

[13] Feez, S. (1998). Text-based syllabus design. Sydney: Macquarie University and AMES.

[14] Flowerdew, J. and Peacock, M. (2001). Research Perspectives on English for Academic Purposes. Cambridge: Cambridge University Press.

[15] Halliday, M. A. K. (1994). An introduction to functional grammar, 2nd edn. London Arnold.

[16] Hutchinson, T. and Waters, A. (1987) English for Specific Purposes. A learning-centred approach. Cambridge: Cambridge University Press.

[17] Hyland, K. and Hamp-Lyons, L. (2002) 'EAP: Issues and directions' In Journal of English for Academic Purposes 1, pp1-12.

[18] Jordan, R. R. (1997) English for Academic Purposes. A guide and resource book for teachers. Cambridge: Cambridge University Press.
[19] Krzanowski, M. (2001). S/he holds the Trinity/UCLES Diploma: Are they ready to teach EAP? Retrieved 26.05.12 from

http://www.baleap.org.uk/pims/pimreports/2001/bath/krzanow ski.htm

[20] Sharpling, G. (2002). Learning to Teach English for Academic Purposes: Some current training and development issues. ELTED 6, pp82-94

[21] Strevens, P. (1988). ESP after 20 years: A reappraisal. In ESP: State of the Art, M. Tickoo (Ed.) pp1-13. Singapore: SEAMEO Regional Language Centre.

[22] Vygotsky, L. (1978). Mind in society: the development of higher psychological processes. M. Cole, V. John-Steiner, S. Scribner and E. Souberman (eds). Cambridge, MA: Harvard University Press.

[23] Watson Todd, R. (2003). EAP or TEAP? Journal of English for Academic Purposes 2, pp147-156. 